\title{
Loricifera inhabiting spherical agglutinated structures in the abyssal eastern equatorial Pacific nodule fields
}

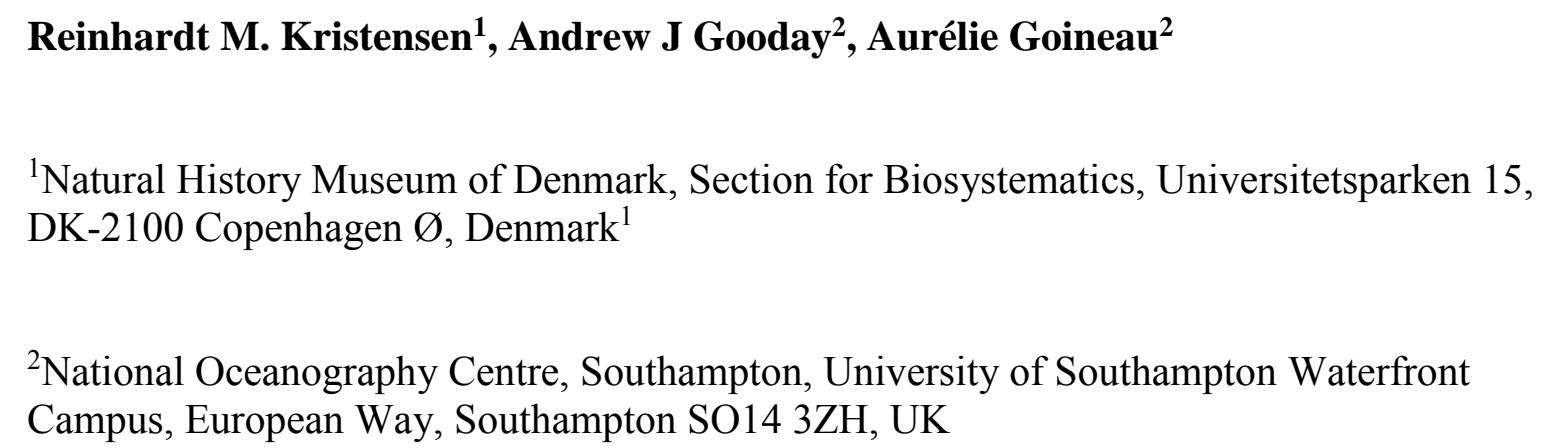

Corresponding author. Andrew Gooday: email: ang@noc.ac.uk; tel: +44 (0)23 80596353 fax:

\section{Acknowledgements}

We thank Craig Smith for his inviting two of us to participate in the ABYSSLINE project and for his management of both the project and the two cruises during which the samples were collected. We also thank Ivan Voltski and Alexandra Weber who supported our work at sea. Support for a visit by the senior author to the National Oceanography Centre, Southampton, was provided by Carlsberg Foundation grant CF-16-0236. Laura Pavesi (NHMD) is acknowledged for the registration of the slides. We thank 4 anonymous Reviewers for their detailed comments that helped to improve the manuscript. The ABYSSLINE project is funded through a commercial arrangement with UK Seabed Resources Ltd, whose support we gratefully acknowledge. 


\begin{abstract}
Loriciferans are known to survive in extreme environments, most notably in the case of a recently described Spinoloricus species from a hypersaline anoxic Mediterranean basin. Our new discovery of members of the genus Rugiloricus inside spherical agglutinated structures from sediment samples collected in the manganese nodules fields of the eastern ClarionClipperton Zone (CCZ, abyssal equatorial Pacific) demonstrates that these tiny animals are able to spring fresh surprises. Nearly all developmental stages of an undescribed Rugiloricus species were found inside the spheres, from the first instar larva and large free larva to the two stages of the postlarva inside the larval exuvium. Only the adults were missing. The spheres themselves were almost certainly not created by the loriciferans. Their origin is unclear, although similar agglutinated structures from the same study area contain cells that resemble monothalamous foraminifera, suggesting that they are possibly made by foraminifera. One of our CCZ samples also yielded a single free specimen of the loriciferan genus Pliciloricus that was not hidden inside an agglutinated structure. This specimen is particularly interesting because, like nested Russian dolls, it has all stages inside the larval exuvium: first the larval exuvium itself with the two toes, then a very thin postlarval exuvium, and finally the adult male with two testes filled with mature spermatozoa.
\end{abstract}

Keywords Metazoan meiofauna. loriciferans. Rugiloricus. Pliciloricus. monothalamous foraminifera. polymetallic nodules. 


\section{Introduction}

The phylum Loricifera was described in 1983 from coarse sand at low water in Roscoff, France (Kristensen, 1983). Since then, 36 loriciferan species have been established (Neves et al., 2018). However, there have been relatively few records of loriciferans from the deep Pacific Ocean. Kristensen and Shirayama (1988), Gad (2004) and Neves and Kristensen (2014) described new genera and species from the western Pacific. In the eastern Pacific, a new genus (Spinoloricus Heiner and Neuhaus, 2007) was described by Heiner and Neuhaus (2007) and a new species of this genus by Neves and Kristensen (2016), in both cases from the equatorial Galapagos Spreading Center. Recently, Neves et al. (2018) established two new species of Rugiloricus Higgins and Kristensen, 1986 and Urnaloricus Heiner and Kristensen, 2009 from the Oregon and Californian margins. However, little attention has been paid to these meiofaunal metazoans in the Clarion-Clipperton Zone (CCZ). This extensive tract of the equatorial Pacific hosts vast deposits of polymetallic nodules of considerable potential economic importance. Because it lies in international waters, commercial activities in the $\mathrm{CCZ}$ are regulated by the International Seabed Authority, a UN body that enters into contracts with companies and governments having interests in seafloor mining (Lodge et al., 2014; Lodge and Verlaan, 2018). The CCZ is currently the focus of a large international research effort to characterise the benthic fauna prior to any future exploitation of this valuable mineral resource (Jones et al., 2018). Radziejewska et al. (2001) and Radziejewska (2002) mention loriciferans (larvae and adults) among the 'less abundant' meiofaunal taxa present in some samples from the Interoceanmetal Joint Organisation (IOM) contract area in the eastern $\mathrm{CCZ}\left(\sim 11^{\circ} 40^{\prime} \mathrm{N}, 119^{\circ} 40^{\prime} \mathrm{W}, \sim 4400 \mathrm{~m}\right.$ depth $)$. Similarly, Mahatma (2009) records loriciferans among the 'rare' or 'very rare' meiofaunal taxa in the French contract area in the more central part of the $\operatorname{CCZ}\left(14^{\circ} \mathrm{N}, 130^{\circ} \mathrm{W}, \sim 5000 \mathrm{~m}\right.$ depth), where they occur in densities of $0-0.05$ indiv.core ${ }^{-1}$. Nothing further has been published, however, about the loriciferans from these two areas.

In 2013 and 2015, we (AJG and AG) took part in two cruises as part of the ABYSSLINE project, a baseline study of benthic fauna in the UK-1 and Ocean Minerals Singapore (OMS) contract areas in the eastern part of the CCZ (Glover et al., 2016). Our main interest was in benthic foraminifera (Goineau and Gooday, 2017; Gooday and Goineau, 2019). However, during the course of this work, we encountered five loriciferans, four of which, all larvae and postlarvae of the genus Rugiloricus, were hidden inside spherical agglutinated structures. The fifth specimen, which was not enclosed in such a structure, belonged to the genus Pliciloricus Higgins and Kristensen, 1986. The purpose of the present note is to 1) report the totally novel occurrence of loriciferans inside agglutinated structures and 2) briefly describe the five loriciferans.

Both Rugiloricus and Pliciloricus are members of the family Pliciloricidae. Fig. 1 (from figure 19 of Neves et al., 2016) illustrates the life-cycle of the Pliciloricidae in order to provide a context for the observations reported here. For a full description of the life-cycle see Neves et al. (2016).

\section{Materials and Methods}

Detailed descriptions of ship-board and laboratory methods are given by Goineau and Gooday, 2017). In brief, samples were collected using a Megacorer (BCMEGA OSIL Bowers and Connelly) equipped with 10-cm-diameter core tubes during ABYSSLINE cruises AB01 (R/V Melville cruise MV1313, 3 to 27 October 2013; Smith et al., 2013) and AB02 (R/V Thomas G Thompson cruise TN319, 12 February to 25 March, 2015) in the UK-1 and OMS 
contract areas. Station details are summarised in Table 1. The sediment was a fine-grained, brown, siliceous (radiolarian) ooze with some diatom frustules and micronodules.

The samples were sliced into horizontal layers $(0.5 \mathrm{~cm}$ thick to $2 \mathrm{~cm}$ depth and thereafter in 1-cm-thick layers down to $10 \mathrm{~cm}$ depth) using a cutting plate, and each sediment slice stored separately in 10\% borax-buffered seawater formalin. In the laboratory, preserved slices were split into $1 / 8$ th fractions using a wet sample splitter (Jensen, 1982). The present observations were made serendipitously during a series of wider studies of foraminifera based on these core slices. All samples yielding loriciferans were sieved on 300 and $150 \mu \mathrm{m}$ mesh screens. For the upper two layers $(0-0.5$ and $0.5-1.0 \mathrm{~cm})$ either three or four $1 / 8^{\text {th }}$ splits were analysed (Table 2). Single splits from two samples (MC09, MC11) were also sieved on 125 and $63 \mu \mathrm{m}$ screens in order to examine foraminifera in these finer fractions. In the case of the MC09 sample, a single split from each of the deeper layers down to $5 \mathrm{~cm}$ was sieved on 300 and $150 \mu \mathrm{m}$ screens. All sieve residues were stained overnight in Rose Bengal and sorted in water for foraminifera and metazoan meiofauna under a stereo-microscope. Loricifera and other metazoans were stored in glycerol in open cavity slides. Specimens were photographed using either an SLR digital camera (Canon EOS 350D) fitted to an Olympus BH2 compound microscope (Southampton) or an Olympus DP27 digital camera fitted to an Olympus BX51 compound microscope (Copenhagen). Finally, all the loriciferans were removed from the open slides in glycerol to permanent slides and the cover slips sealed with Glyceel. This unique material, a total of six slides, is deposited in the loriciferan collection at the Natural History Museum of Denmark under the numbers NHMD 287289 to 287294.

\section{Results}

Five loriciferans were sorted from 150-300 $\mu \mathrm{m}$ sediment fractions; none were found in the $>300 \mu \mathrm{m}, 125-150 \mu \mathrm{m}$ or $63-125 \mu \mathrm{m}$ sieve fractions. Two originated from the $0-0.5 \mathrm{~cm}$ sediment layer (MC11, MC25), two from the 0.5-1.0 cm layer (both MC25), and the fifth from the 3-4 cm layer (MC09) (Table 2). Four specimens (from MC09, MC11 and MC22), were found inside more or less spherical agglutinated structures (Fig. 2a,b,e; Fig. 3a,b,e) measuring 230 - $275 \mu \mathrm{m}$ in diameter (Table 3 ). The spheres had a wall composed of finely agglutinated grains through which the loriciferans were visible when viewed in transmitted light. The wall sometimes incorporated a radiolarian test. The spheres were flexible and so presumably included some organic matrix. In three cases, the wall could be pulled apart with a pair of dissecting needles fairly easily to release the loriciferans (Fig. 3b). However, the sphere from sample MC09, although soft and easily distorted (Fig. 2b,c), proved to be resistant to tearing, making it impossible to extract the inhabitant.

The lengths of all specimens are given in Table 3. The two specimens from samples MC09 and MC11 were larvae (Fig. 2b,d,f) while sample MC22 yielded two larval moults containing developing post-larvae (Fig. 3c,d,f). All are considered to represent an undescribed species of the genus Rugiloricus. The fifth specimen from sample MC20, which unlike the other four was not associated with an agglutinated sphere, was a last instar Higgins larva containing a postlarval form moulting to an adult male of the genus Pliciloricus (Figs 4 and 5). Unfortunately we could not establish new species based on this small collection. In the case of Rugiloricus, the adult stage was lacking. In the case of the new Pliciloricus, many of the morphological characters, such as all the scalids of the introvert and the lorica type of the adult male, could not be observed inside the larva/postlarva exuvium. Therefore we only give a short description of the five loriciferans. 
1) Rugiloricus-larva (sample MC09, Figs 2a-d; corresponding to stage ' $\mathrm{C}$ ' in Fig. 1). This is the first instar Higgins larva of the genus Rugiloricus. The pharyngeal bulb is filled with glandular tissue and two giant nuclei (nu) are seen in the middle of the pharyngeal bulb (ph). The abdomen $(\mathrm{ab})$ is filled with absorptive and glandular cells, which would only be present if substantial amounts of food material had been ingested. The larva could not be removed from the agglutinated sphere, which was relatively cohesive and deformed when attempts were made to tear it open.

2) Rugiloricus-larva (sample MC11, Figs 2 e, f; corresponding to stage 'D' in Fig. 1). This specimen is clearly the last instar of the loriciferan Higgins larva, just before moulting to the postlarva (Higgins and Kristensen, 1986). Both the pharyngeal bulb (ph) and the midgut (mg) are clearly visible. The two toes (to) are of the Rugiloricus carolinensis Higgins and Kristensen, 1986 type (Heiner, 2008). The larva could easily be removed from the agglutinated sphere.

3) Late Rugiloricus-postlarva inside the Higgins larval exuvium (sample MC22, Figs 3a,c,d; corresponding to stage ' $\mathrm{N}$ ' in Fig. 1). The postlarva was clearly visible when the loriciferan was first observed within the agglutinated sphere (Fig. 3a). However, in addition to the late developing postlarva, the sphere also contained the very thin larval exuvium, which became obvious when the loriciferan was removed (Fig. 3c,d). The larval exuvium has all the characters of a Rugiloricus species; the combination of short toes (to), long unbranched anterior lateroventral seta (alv) and the moulted larval scalids ( $\left.\mathrm{sc}_{1}\right)$ seen anterior to the postlarva (po) is found only in this genus. The new scalids can be seen protruding from the introvert (head) in Fig.3c The postlarva is only $98 \mu \mathrm{m}$ long

4) Early Rugiloricus-postlarva inside the Higgins larva exuvium (sample MC22; Figs 3ef, corresponding to stage ' $\mathrm{N}$ ' in Fig. 1). Only the postlarva was clearly visible within the agglutinated sphere containing the loriciferan when it was first observed (Fig. 3e). The larval exuvium, as well as the early developed postlarva, were obvious when they were removed from the structure. The larval exuvium displays many of the same characters as the specimen in Fig. 3a-d and the posterolateral seta $\left(\mathrm{se}_{2}\right)$ can also be seen. However, this postlarva lacks obvious scalids. The postlarva is also only $98 \mu \mathrm{m}$ long, making the two specimens from MC22 the smallest recorded loriciferan postlarvae.

5) Pliciloricus (sample MC25; Figs 4 and 5, corresponding to stage ' $\mathrm{O}$ ' in Fig. 1). This specimen encompasses three stages in one specimen: the Higgins larval exuvium with toes (to), a very thin postlarval exuvium, and the adult male with two testes (te) containing mature spermatozoa (sz). Fig 4a,b illustrate the larval structures: the toes and the larval setae. In Fig $4 \mathrm{c}, \mathrm{d}$ all adult characters are seen, revealing that the animal is a male with two testes. The spermatozoa (sz) are of the Pliciloricus-type (see Kristensen, 1991a). Finally, Fig.5 shows the moulted larval internal armature (ia) and the toes (to), clearly indicating that the specimen is a Pliciloricus.

\section{Discussion}

Except in the hypersaline, permanently anoxic, sulphidic environment of the l'Atalante Basin in the deep Mediterranean (3363-3600 $\mathrm{m}$ water depth), where they are the only living metazoans (Danovaro et al., 2010, Neves et al., 2014), loriciferans are usually an occasional element of deep-sea meiofaunal assemblages, for example, representing only $0.10 \%$ of meiofaunal animals in the case of abyssal samples from the Angola Basin (SW Atlantic) (Gad, 2005a). Shallow-water loriciferans typically live interstitially in sandy substrates and shell gravel, whereas lower bathyal and abyssal species usually inhabit fine-grained, often muddy sediments (Neves et al., 2016; Neves et al., 2018). Little is known about their biology, 
although like their relatives in coastal waters (Kristensen, 1991b), deep-sea species are probably bacterivores.

Our samples from the UK-1 and OMS contract areas yielded four larvae and postlarvae of the loriciferan genus Rugiloricus found inside agglutinated spheres, in addition to a single free Higgins larva of Pliciloricus. Both of these genera have been reported previously from deep-sea settings; Rugiloricus from the Indian (3400 m depth) and Arctic (1210 m depth) Oceans (Kristensen et al., 2013; Gad and Martinez Arbizu, 2005), Pliciloricus from the upper bathyal NW Atlantic (293-439 m), the abyssal SE Atlantic (5388$5448 \mathrm{~m}$ ), and at hadal depths (8260 m) in the NW Pacific (Higgins and Kristensen, 1986; Kristensen and Shirayama, 1988; Gad, 2004, 2009), and both genera from the Galapagos Spreading Centre (Heiner and Neuhaus, 2007) in the bathyal eastern equatorial Pacific (2121$2776 \mathrm{~m}$ ). However, this is the first time that either genus has been recorded in samples from the CCZ or indeed in any area of seafloor hosting polymetallic nodules.

We are also unaware of any previous records of loriciferans residing inside agglutinated structures, perhaps because they are difficult to spot when hidden within these microhabitats. Figure 6a shows a group of agglutinated structures from the 150-300 $\mu \mathrm{m}$ fraction of the M22 sample. It includes one of those that contained a loriciferan, as well as three radiolarian tests inhabited by benthic foraminifera, and an agglutinated structure containing a cell-like body. Radiolarian tests occupied by foraminifera are very common in our samples (Goineau and Gooday, 2015). Spheres with loriciferans may be difficult to distinguish from them at first sight, particularly under a stereo-microscope, although the radial spines of radiolarians usually become obvious when specimens are viewed under a compound microscope. Our serendipidous observations, although limited, suggest that loriciferans may be more common in this part of the Pacific than is apparent from current records (Mahatma, 2009).

It is intriguing that all four Rugiloricus Higgins larvae/postlarvae were living inside spheres while the single Pliciloricus specimen, comprising the larval exuvium and postlarval exuvium with the mature male inside, was found free in the sieved sediment residue. It would be interesting to know whether this is a coincidence or a consistent relationship, although a much larger number of specimens would be required to resolve this question. The nature of the agglutinated structures containing the loriciferans is also unclear. It seems highly unlikely that they are created by the loriciferans themselves, while the absence of a skeletal framework confirms that they are not spherical radiolarian tests. The structures are most similar to tests of the spherical, single-chambered agglutinated foraminifera (monothalamids) that are particularly abundant in the fine sieve fractions of abyssal Pacific samples (Nozawa et al., 2006; Ohkawara et al., 2009). In Fig. 6c,d we show two examples of spherical monothalamids with dark stercomata (waste pellets) that are very common in our samples. However, the spheres containing loriciferans were larger $(230-275 \mu \mathrm{m})$ than most of the monothalamid tests present in our samples (generally $<150 \mu \mathrm{m}$ ) and their walls were also finer-grained and rather thicker. Except for the specimen from MC09, they could be torn open but still retain their basic shape (Fig. 3a,b) whereas monothalamid spheres tend to disintegrate. Finally, there is no trace of stercomata within the loriciferan spheres. The identity of these microhabitats is therefore unresolved, although a foraminiferal origin still remains the most likely possibility. Indeed, the two spherical structures containing cell bodies illustrated in Figs 6e,f are very similar to those hosting the loriciferans. These are possibly allogromiid foraminifera inside resting or feeding cysts (Heinz et al., 2005).

Why the loriciferans occupy agglutinated spheres is equally unclear. Possibly, these microhabitats resemble the interstitial spaces that loriciferans inhabit in much coarser-grained shallow-water sediments, although this does not explain how the Rugiloricus-larva can obtain enough food to support growth and moulting to a postlarva inside them. Another possibility, 
therefore, is that these structures may host enhanced bacterial populations that the larva (although not the postlarva contained within the moult) can use as a food source. This could explain why they contain nearly the whole life-cycle of the loriciferans. However, since only larvae and postlarvae were found within the spheres, there is no evidence that the adults obtain any benefit from the occupancy of this microhabitat.

The Pliciloricus specimen comprised the larval exuvium with its two toes enclosing a very thin postlarval exuvium, and finally the mature adult male. Higgins and Kristensen (1986, Fig. 3) illustrated the paratypic larva of Pliciloricus enigmaticus Higgins and Kristensen, 1986 moulting into an adult male. In addition, Gad (2005b) illustrated an adult female and an immature adult of $P$. peduncularis Gad, 2005 nested within postlarval and larval exuvia (see figures $3 \mathrm{~b}$ and $7 \mathrm{in} \mathrm{Gad,} \mathrm{2005b).} \mathrm{However,} \mathrm{our} \mathrm{specimen} \mathrm{is} \mathrm{really} \mathrm{unique}$ because the three stages are very condensed, so that the adult completely fills the postlarval structures are visible.

\section{Concluding remarks}

Very little is known about loriciferans within the CCZ, part of the equatorial Pacific that hosts commercially significant deposits of polymetallic nodules. In samples from the eastern CCZ, we observed undescribed larvae and postlarvae of the genus Rugiloricus and an adult Pliciloricus (also undescribed) nested like a Russian doll inside a postlarval exuvium that itself was nested inside a Higgins larval exuvium. Most interestingly, the Rugiloricus specimens occupied agglutinated spheres of uncertain origin, the first time such an association has been reported. The loriciferans were difficult to see inside these microhabitats and could be easily overlooked. What benefit they derived from this mode of life is unknown but a future investigation of potential food sources (e.g., bacteria and other micro-organisms) associated with the structures might prove fruitful. There is clearly much to be learnt about the ecology, as well as the distribution, of these remarkable animals in the CCZ, and elsewhere in the deep ocean. 
Funding RMK received funding from the Carlsberg Foundation grant CF-16-0236. The wider ABYSSLINE project, including the salary of AG, part of the salary of AJG, and costs associated with the two cruises, were funded by UK Seabed Resources Ltd under contract number SRD100300.

\section{Compliance with ethical standards}

Conflict of interest. The authors declare no conflicts of interest.

Ethical approval. This article does not contain any studies with animals performed by any of the authors.

Sampling and field studies. The sampling was conducted in international waters within areas covered by contracts for seabed exploration issued by the International Seabed Authority.

\section{Data availability statement}

All data generated or analysed during this study are included in this published article.

\section{References}

Danovaro D, Dell'Anno A, Pusceddu A, Gambi C, Heiner I, Kristensen RM (2010) The first metazoa living in permanently anoxic conditions. BMC Biol 8: 30. https://doi.org/10.1186/1741-7007-8-30

Gad G (2004) A new genus of Nanaloricidae (Loricifera) from deep-sea sediments of volcanic origin in the Kilinailau Trench north of Papua New Guinea. Helgol Mar Res 58: 40-53.

Gad G (2005a) Giant Higgins-larvae with paedogenetic reproduction from the deep sea of the Angola Basin - evidence for a new life cycle and for abyssal gigantism in Loricifera? Org Divers Evol 5 (suppl. 1): 44-59.

Gad G (2005b) A parthenogenetic, simplified adult in the life cycle of Pliciloricus pedicularis sp. n. (Loricifera) from the deep sea of the Angola Basin (Atlantic). Org Divers Evol 5: 77-103

Gad G (2009) A clearly identifiable postlarva in the life cycle of a new species of Pliciloricus (Loricifera) from the deep sea of the Angola Basin. Zootaxa 2096: 50-81

Gad G, Martínez Arbizu P (2005) First report of Arctic Loricifera - a new Rugiloricusspecies from the Laptev Sea. Mar Biol Res 1: 313-325.

Glover AG, Dahlgren T, Wiklund H, Mohrbeck I, Smith C R (2016) An end-to-end DNA taxonomy methodology for benthic biodiversity survey in the Clarion-Clipperton Zone, central Pacific Abyss. J Mar Sci Engineering, 4: 2. http://doi.org./10.3390/jmse4010002

Goineau A, Gooday AJ (2015) Radiolarian tests as microhabitats for novel benthic foraminifera: observations from the abyssal eastern equatorial Pacific (ClarionClipperton Fracture Zone). Deep-Sea Res I 103: 73-85. http://doi.org/10.1016/j.dsr.2015.04.011 
Goineau A, Gooday AJ (2017) Novel benthic foraminifera are abundant and diverse in an area of the abyssal equatorial Pacific licensed for polymetallic nodule exploration. Sci Rep 7. 45288. http://doi.org/10.1038/srep45288.

Gooday AJ, Goineau A (2019) The contribution of fine sieve fractions $(63-150 \mu \mathrm{m})$ to foraminiferal abundance and diversity in an area of the eastern Pacific Ocean licensed for polymetallic nodule exploration. Front Mar Sci. http://doi:10.3389/fmars.2019.00114

Heiner, I. (2008) Rugiloricus bacatus sp. nov. (Loricifera-Pliciloricidae) and a ghost larva with paedogenetic reproduction. Syst Biodiv 6: 225-247.

Heiner I, Kristensen RM (2009) Urnaloricus gadi nov. gen. et nov. sp. (Loricifera, Urnaloricidae nov. fam.), an aberrant Loricifera with a viviparous pedogenetic life cycle. J Morphol 270: 129-153

Heiner I, Neuhaus B (2007) Loricifera from the deep sea at the Galápagos Spreading Center, with a description of Spinoloricus turbatio gen. et sp. nov. (Nanaloricidae). Helgol Mar Res 61: 167-182.

Heinz P, Geslin E, Hemleben C, 2005. Laboratory observations of benthic foraminiferal cysts. Mar Biol Res 1: 149-159. http://dx.doi.org/10.1080/17451000510019114

Higgins RP, Kristensen RM (1986) New Loricifera from South-eastern United States Coastal Waters. Smithson Contrib Zool 438: 1-70.

Jensen P (1982). A new meiofaunal splitter. Ann. Zool. Fennici 19: 233-236.

Jones DOB, Amon DJ, Chapman ASA (2017) Mining deep-ocean deposits: what are the ecological risks. Elements 14: 325-330.

Kristensen RM (1983) Loricifera, a new phylum with Aschelminthes characters from the meiobenthos. Z Zool Syst Evolutionsforsch 21: 163-180.

Kristensen RM (1991a) Loricifera. In: Harrison FW, Ruppert EE (eds). Microscopic Anatomy of Invertebrates, Vol 4, Aschelminthes. Wiley-Liss, New York, pp 351-375.

Kristensen RM (1991b) Loricifera - a general biological and phylogenetic overview. Verh. Dtsch Zool Ges 84: 231-246.

Kristensen RM, Shirayama Y (1988) Pliciloricus hadalis (Pliciloricidae), a new Loriciferan species collected from the Izu- Ogasawara Trench, Western Pacific. Zool Sci 5: 875881.

Kristensen RM, Neves RC, Gad G (2013) First report of Loricifera from the Indian Ocean: a new Rugiloricus species represented by a hermaphrodite. Cah Biol Mar 54: 161-171.

Lodge M, Johnson D, Le Gurun G, Wengler M, Weaver P, Gunn V (2014) Seabed mining: International Seabed Authority environmental management plan for the ClarionClipperton Zone. Mar Policy 49: 66-72.

Lodge M, Verlaan PA (2018) Deep-Sea mining: international regulatory challenges and responses. Elements 14: 331-336

Mahatma R (2009) Meiofauna Communities of the Pacific Nodule Province: abundance, diversity and community structure. PhD Thesis, University of Oldenburg, $143 \mathrm{pp}$. Available at http://oops.uni-oldenburg.de/1009/1/mahmei09.pdf.

Neves RC, Kristensen RM (2014) A new type of loriciferan larva (Shira larva) from the deep sea of Shatsky Rise, Pacific Ocean. Org Divers Evol 14: 163-171. http://doi.org/10.1007/s13127-013-0160-4

Neves RC, Kristensen RM (2016) Spinoloricus neuhausi (Loricifera, Nanaloricidae), a new deep sea species from Galápagos Spreading Center. Zool Anz 265: 171-177, http://dx.doi.org/10.1016/j.jcz.2016.01.001.

Neves RC, Gambi C, Danovaro R, Kristensen, RM (2014) Spinoloricus cinziae (Phylum Loricifera) a new species from a hypersaline anoxic deep basin in the Mediterranean Sea. Syst Biodivers 12: 489-502. 
Neves RC, Reichert H, Sørensen MV, Kristensen RM (2016) Systematics of phylum Loricifera: identification keys of families, genera and species. Zool Anz 265:141-170

Neves RC, Kristensen RM, Rohal M, Thistle D, Sørensen MV (2018) First report of Loricifera from the North East Pacific Region, with the description of two new species. Mar Biodiv. https://doi.org/10.1007/s12526-018-0898-1

Nozawa F, Kitazato H, Tsuchiya M, Gooday AJ (2006) 'Live' benthic foraminifera at an abyssal site in the equatorial Pacific nodule province: abundance, diversity and taxonomic composition. Deep-Sea Res I 51: 1406-1422.

Ohkawara N, Kitazato H, Uematsu K, Gooday AJ (2009) A minute new genus and species of monothalamous Foraminifera (Protista) from the abyssal Pacific. J Micropalaeontol 20: $143-151$.

Radziejewska T (2002) Responses of deep-sea meiobenthic communities to sediment disturbance simulating effects of polymetallic nodule mining. Int Rev Hydrobiol 87: 457-477.

Radziejewska T, Rokicka-Praxmajer J, Stoyanova V (2001) IOM BIE revisited: meiobenthos at the IOM BIE site 5 years after the experimental disturbance. Proceedings of the fourth (2001) Ocean Mining Symposium, Szczecin, Poland, September 23-27, 2001, p. 63-68.

Smith CR, Dahlgren TG, Drazen J, Gooday AJ, Glover AG, Kurras G, Martinez AP, Shulse C, Spickermann R, Sweetman AK, Vetter E. (2013) Abyssal Baseline Study (ABYSSLINE) Cruise Report. Seafloor Investigations Report 2013-1304-051JSRDL-AB01. 


\section{Figure captions}

407 Fig. 1 Life cycle of the family Pliciloricidae (after figure19 in Neves et al., 2016). The loriciferans described here correspond to C (first instar of Higgins larva; Fig. 2a-d), D (late instar of Higgins larva; Fig. 2e,f), N (last instar of Higgins larva with postlarva inside; Fig. 3c,d,f), and $\mathrm{O}$ (last instar of Higgins larva with postlarva and the young male inside; Figs 3,4). Reprinted from Zoologischer Anzeiger, vol. 265, R.C. Neves, H. Reichert, M.V. Sørensen, R.M. Kristensen, Systematics of phylum Loricifera: Identification keys of families, genera and species, pp. 141-170, 2016, with permission from Elsevier.

Fig. 2 Light micrographs of undescribed Rugiloricus Higgins larvae inhabiting agglutinated structures. a-d Specimen from MC09 (3-4 cm layer). a 1st instar Higgins larva as first found inside agglutinated sphere. b Agglutinated sphere distorted after attempts to extract larva. c, d Same larva viewed using differential interference contrast. e, f Sample MC11 (0-0.5 cm layer). e Late instar Higgins larva as first found inside agglutinated sphere. f Same larva after removal from sphere. Abbreviations: $\mathrm{ab}=$ abdomen; in = introvert; $\mathrm{mg}=$ midgut; $\mathrm{ph}=$ pharyngeal bulb; $\mathrm{se}_{1}=$ posterodorsal seta; to $=$ toes. Scale bars $=100 \mu \mathrm{m}(\mathbf{a}-\mathbf{c}, \mathbf{e}), 50 \mu \mathrm{m}(\mathbf{d}$, f)

Fig. 3 Light micrographs of undescribed Rugiloricus larval moult containing postlarvae and associated agglutinated structure from sample MC22 (0-0.5 cm layer). a-d Specimen 1. a Agglutinated structure containing loriciferan as first found. $\mathbf{b}$ Remains of agglutinated structure after removal of loriciferan. $\mathbf{c}, \mathbf{d}$ Specimen removed from sphere, viewed using differential interference contrast (DIC). e, f Specimen 2. e Agglutinated structure containing loriciferan as first found. f Specimen removed from sphere, viewed using DIC.

Abbreviations: alv = anterior lateroventral seta; $\mathrm{po}=$ postlarva; $\mathrm{sc}=$ moulted larval scalids; $\mathrm{se}_{2}=$ posterolateral seta; to $=$ larval toes. Scale bars $=100 \mu \mathrm{m}$

Fig. 4 Light micrographs of undescribed Pliciloricus (last instar Higgins larva with very thin cuticle of postlarva and young male inside) from Sample MC25 (0-0.5 cm layer). a Specimen as first found, stained with Rose Bengal. b-d. Specimen viewed using differential interference contrast. b View with one toe clearly shown. c, d Photographs with morphological features labelled. Abbreviations: alv $=$ anterior laterovental seta (Higgins larva); br = brain (adult); ca = cuticle (adult); cs = clavoscalids (adult); le = exuvium (Higgins larva); $\mathrm{mc}=$ mouth cone (adult); $\mathrm{mg}=$ midgut (adult); $\mathrm{mt}=$ mouth tube (adult); ple = postlarval exuvium; ru = ruff (adult); $\mathrm{sc}_{\mathrm{a}}=$ spinoscalids (adult); $\mathrm{sc}_{\mathrm{l}}=$ scalids of moulted Higgins larva; $\mathrm{se}_{2}=$ posterolateral seta (Higgins larva); $\mathrm{sz}=$ spermatozoa (adult); te = testis (adult); to $=$ larval toes (Higgins larva). Scale bars $=50 \mu \mathrm{m}$.

Fig. 5 Differential interference contrast micrographs of undescribed Pliciloricus from sample MC25 (0-0.5 cm layer). This is the same animal as in Fig. 4. Abbreviations: alv = anterior lateroventral seta (moulted Higgins larva); br = brain (adult); ia = internal (prepharyngeal) armature (Higgins larva); in = introvert (adult); ru = ruff (adult); $\mathrm{sc}_{1}=$ scalids (Higgins larva); $\mathrm{se}_{2}=$ posterolateral setae (Higgins larva); to = larval toe (Higgins larva). Scale bars $=20 \mu \mathrm{m}$ (a-c), $50 \mu \mathrm{m}$

Fig. 6 Light micrographs of various spherical structures from ABYSSLINE samples. a Group from sample MC22 (0.5-1.0 cm, 150-300 $\mu \mathrm{m}$ fraction) including: sphere with Rugiloricus larval moult containing postlarvae (specimen 1; largest sphere on left), three radiolarian tests hosting foraminiferal inhabitants ( 3 spherical structures on right-hand side), and an 
455 agglutinated structure containing a cell-like body, possibly an organic-walled monothalamid 456 foraminiferan (top centre). b Radiolarian test hosting 4 spherical monothalamous 457 foraminifera; from sample MC20 $(0.5-1.0 \mathrm{~cm}, 150-300 \mu \mathrm{m}$ fraction $)$. c.d Two different kinds 458 of spherical monthalamids containing dark stercomata (waste material); from sample MC11 459 (0-0.5 cm, 63-125 $\mu \mathrm{m}$ fraction). e Agglutinated sphere containing cell with prominent 460 nucleus; this is from the same sample as the loriciferan (MC22) and probably the same as the 461 structure in Fig 6a, top centre. f Similar sphere containing cell body stained with Rose

462 Bengal; from sample MC05 (0-0.5 cm, 63-125 $\mu \mathrm{m}$ fraction). Scale bars $=200 \mu \mathrm{m}(\mathbf{a}), 50 \mu \mathrm{m}$ 463 (b-f) 
3 Table 1. Station details. $\mathrm{MC}=$ Megacorer

4

\begin{tabular}{llllll} 
Cruise & Site & Sample & Latitude $^{\circ} \mathbf{N}$ & Longitude $^{\circ} \mathbf{W}$ & Water depth (m) \\
\hline AB01 & H & MC09 & $13^{\circ} 53.300^{\prime}$ & $116^{\circ} 41.399^{\prime}$ & 4150 \\
AB01 & J & MC11 & $13^{\circ} 54.104^{\prime}$ & $116^{\circ} 35.402^{\prime}$ & 4166 \\
AB02 & S08 & MC22 & $12^{\circ} 11.409^{\prime}$ & $117^{\circ} 22.384^{\prime}$ & 4179 \\
AB02 & U15 & MC25 & $12^{\circ} 34.953^{\prime}$ & $116^{\circ} 39.058^{\prime}$ & 4224
\end{tabular}

5 
1

2

3 Table 2. Sediment layers and sieve fractions analysed for each of the samples in which loriciferans were found. The figures in columns 3-6 4 indicate the numbers of eighth splits sorted in each sieve residue.

5

\begin{tabular}{|c|c|c|c|c|c|c|}
\hline Sample & Sediment layer & & Sieve f & $\operatorname{action}(\mu \mathrm{I}$ & & Reference \\
\hline & & $>300$ & $150-300$ & $125-150$ & 63-125 & \\
\hline MC09 & $\begin{array}{l}0-0.5 \mathrm{~cm} \\
0.5-1.0 \mathrm{~cm} \\
1.0-1.5 \mathrm{~cm} \\
1.5-2.0 \mathrm{~cm} \\
2.0-3.0 \mathrm{~cm} \\
3.0-4.0 \mathrm{~cm} \\
4.0-5.0 \mathrm{~cm}\end{array}$ & $\begin{array}{l}3 / 8 \\
3 / 8 \\
1 / 8 \\
1 / 8 \\
1 / 8 \\
1 / 8 \\
1 / 8\end{array}$ & $\begin{array}{l}3 / 8 \\
3 / 8 \\
1 / 8 \\
1 / 8 \\
1 / 8 \\
1 / 8 \\
1 / 8\end{array}$ & $\begin{array}{l}1 / 8 \\
1 / 8\end{array}$ & $\begin{array}{l}1 / 8 \\
1 / 8\end{array}$ & $\begin{array}{l}\text { Goineau \& Gooday (2017) } \\
\text { Goineau \& Gooday (unpublished) } \\
\text { Gooday and Goineau (2019) }\end{array}$ \\
\hline MC11 & $\begin{array}{l}0-0.5 \mathrm{~cm} \\
0.5-1.0 \mathrm{~cm}\end{array}$ & $\begin{array}{l}3 / 8 \\
3 / 8\end{array}$ & $\begin{array}{l}3 / 8 \\
3 / 8\end{array}$ & $\begin{array}{l}1 / 8 \\
1 / 8\end{array}$ & $\begin{array}{l}1 / 8 \\
1 / 8\end{array}$ & $\begin{array}{l}\text { Goineau \& Gooday (2017) } \\
\text { Goineau \& Gooday (submitted) } \\
\text { Gooday and Goineau (2019) }\end{array}$ \\
\hline MC22 & $\begin{array}{l}0-0.5 \mathrm{~cm} \\
0.5-1.0 \mathrm{~cm}\end{array}$ & $\begin{array}{l}3 / 8 \\
3 / 8\end{array}$ & $\begin{array}{l}3 / 8 \\
3 / 8\end{array}$ & & & $\begin{array}{l}\text { Goineau \& Gooday (2017) } \\
\text { Goineau \& Gooday (submitted) }\end{array}$ \\
\hline MC25 & $\begin{array}{l}0-0.5 \mathrm{~cm} \\
0.5-1.0 \mathrm{~cm}\end{array}$ & $\begin{array}{l}4 / 8 \\
4 / 8\end{array}$ & $\begin{array}{l}4 / 8 \\
4 / 8\end{array}$ & & & $\begin{array}{l}\text { Goineau \& Gooday (2017) } \\
\text { Goineau \& Gooday (submitted) }\end{array}$ \\
\hline
\end{tabular}

6 
1

2 Table 3. Identity and dimensions of Loricifera and associated agglutinated spheres 3

\begin{tabular}{|c|c|c|c|c|c|c|}
\hline Sample & $\begin{array}{l}\text { Sediment } \\
\text { layer }\end{array}$ & Genus & $\begin{array}{l}\text { Sphere } \\
\text { diameter }\end{array}$ & $\begin{array}{l}\text { Length } \\
\text { of larva }\end{array}$ & $\begin{array}{l}\text { Length of } \\
\text { postlarva }\end{array}$ & $\begin{array}{l}\text { Registration } \\
\text { number }\end{array}$ \\
\hline MC09 & $3-4 \mathrm{~cm}$ & Rugiloricus & $230 \mu \mathrm{m}$ & $171 \mu \mathrm{m}$ & - & NHMD 287289 \\
\hline MC11 & $0-0.5 \mathrm{~cm}$ & Rugiloricus & $248 \mu \mathrm{m}$ & $173 \mu \mathrm{m}$ & - & NHMD 287290 \\
\hline MC22-1 & $0.5-1.0 \mathrm{~cm}$ & Rugiloricus & $275 \mu \mathrm{m}$ & $212 \mu \mathrm{m}$ & $98 \mu \mathrm{m}$ & NHMD 287291 \\
\hline MC22-2 & $0.5-1.0 \mathrm{~cm}$ & Rugiloricus & $263 \mu \mathrm{m}$ & $218 \mu \mathrm{m}$ & $98 \mu \mathrm{m}$ & NHMD 287292 \\
\hline MC25 & $0-0.5 \mathrm{~cm}$ & Pliciloricus & - & $209 \mu \mathrm{m}$ & - & NHMD 287293 \\
\hline
\end{tabular}




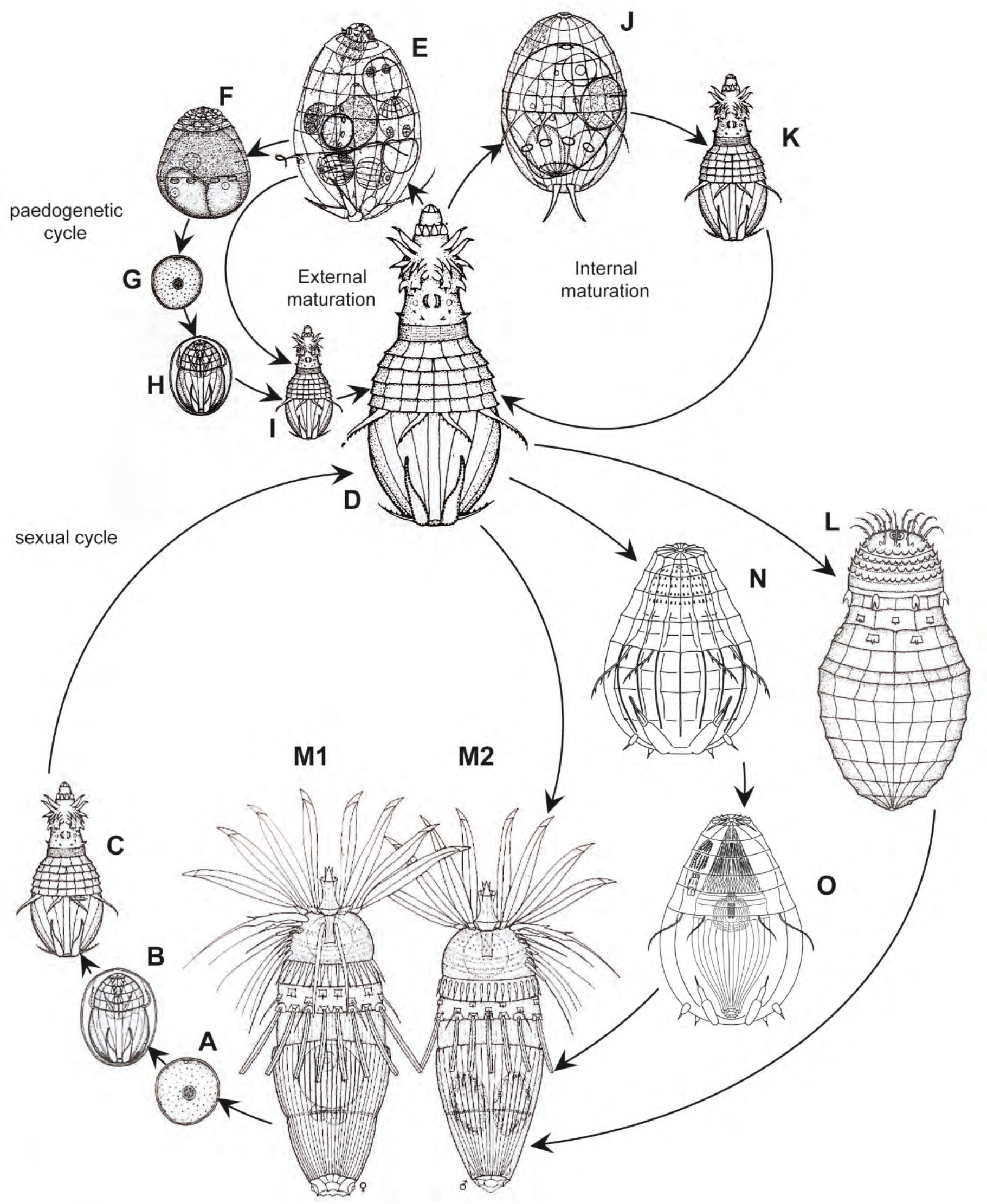




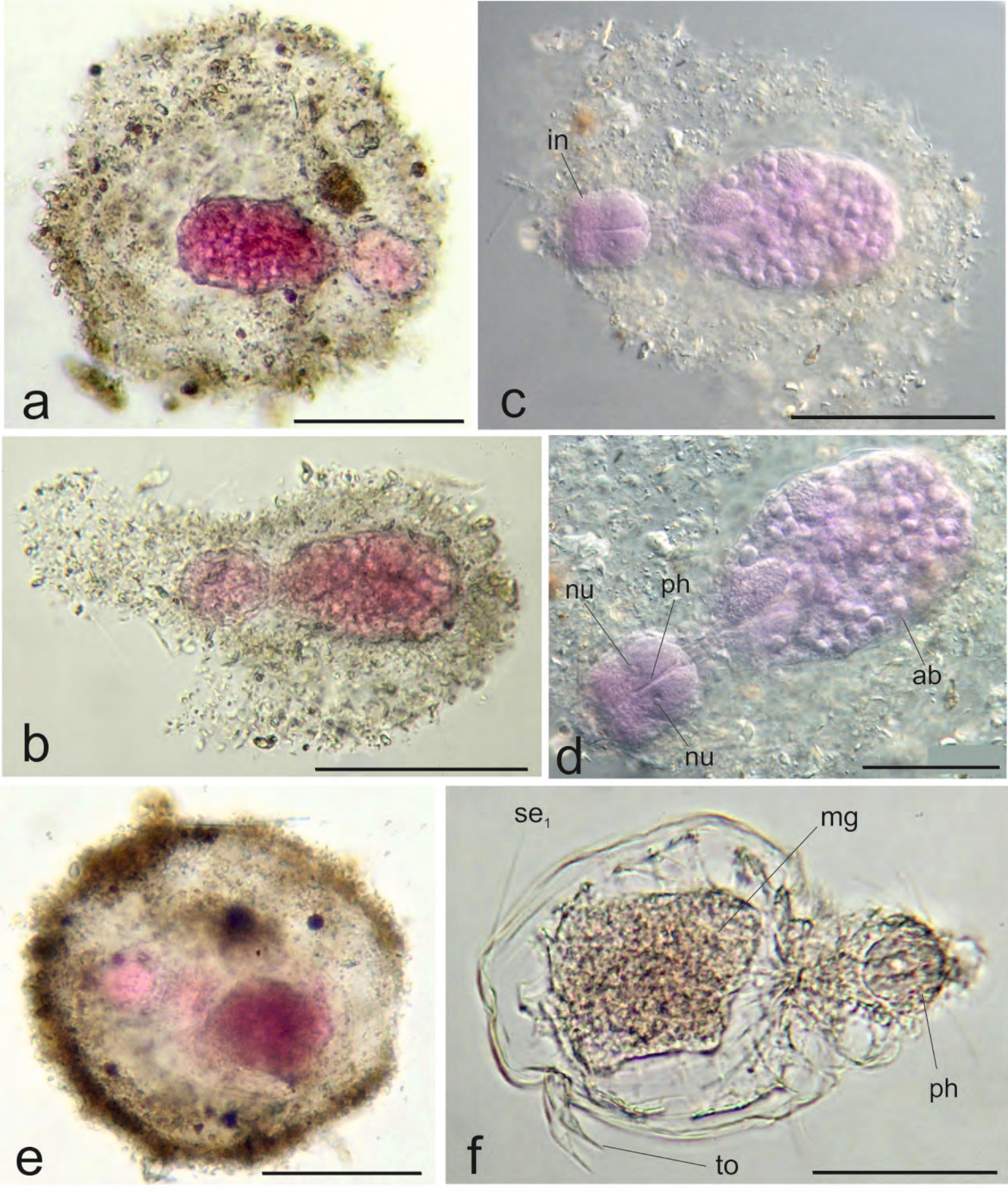



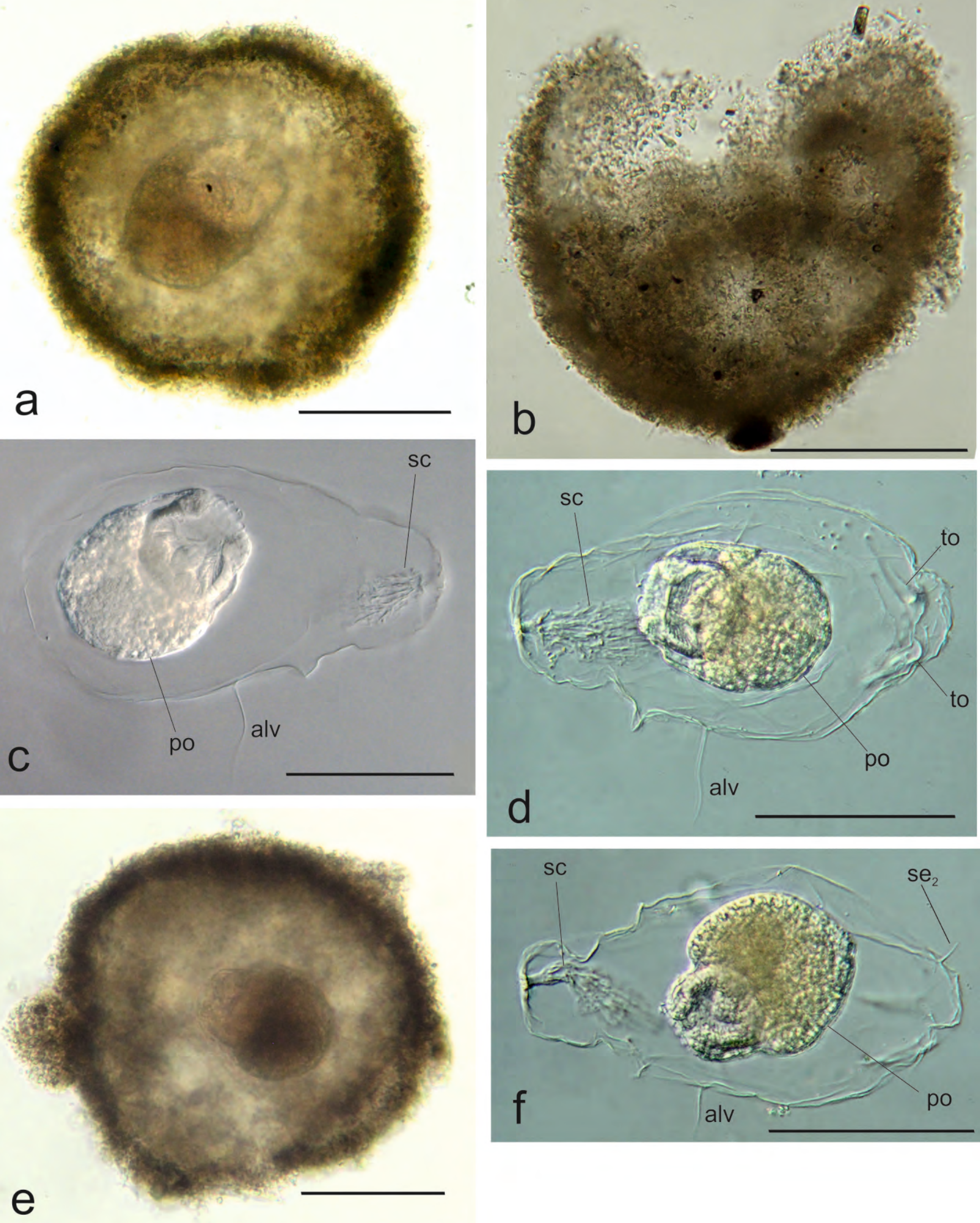


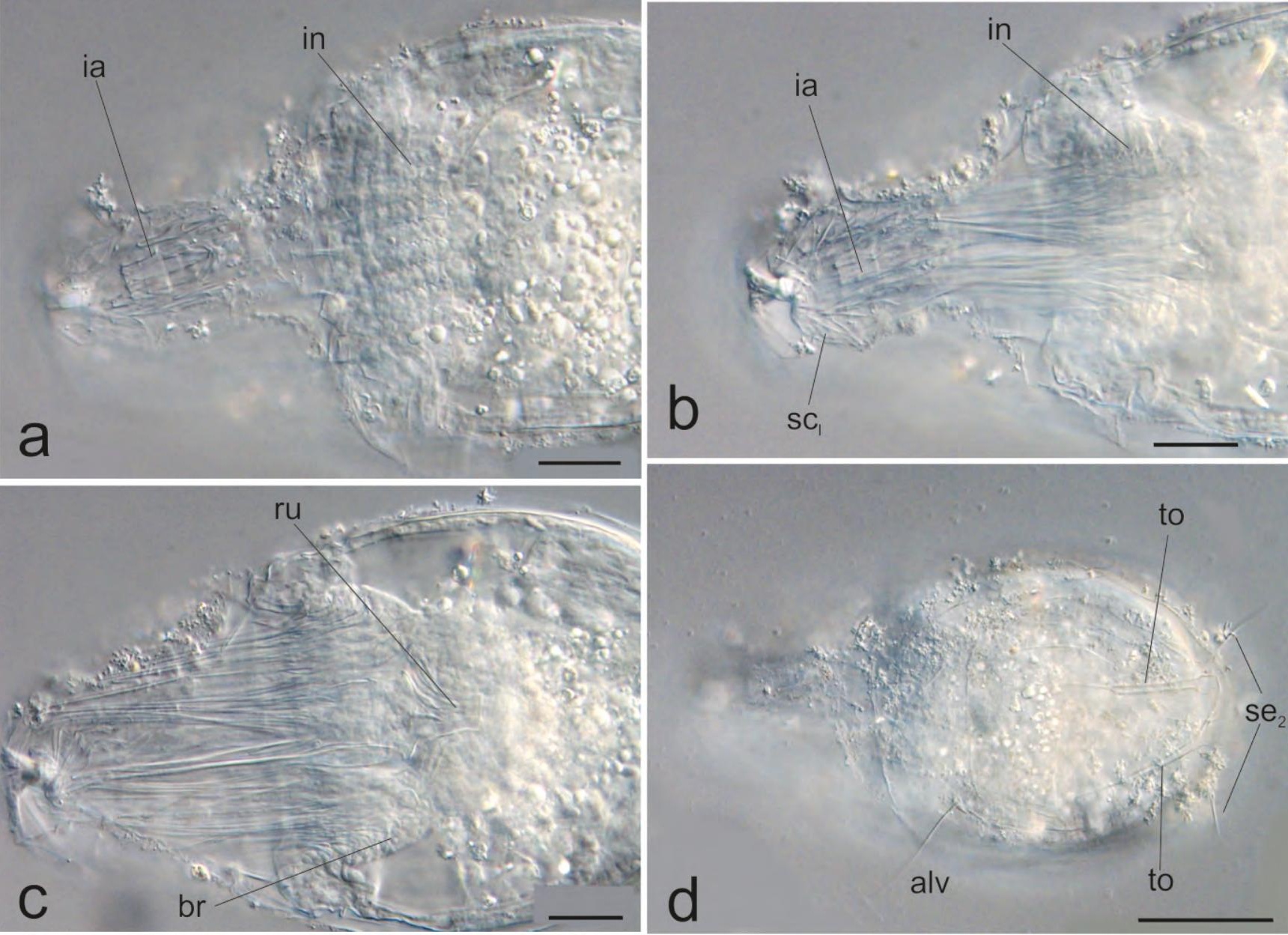



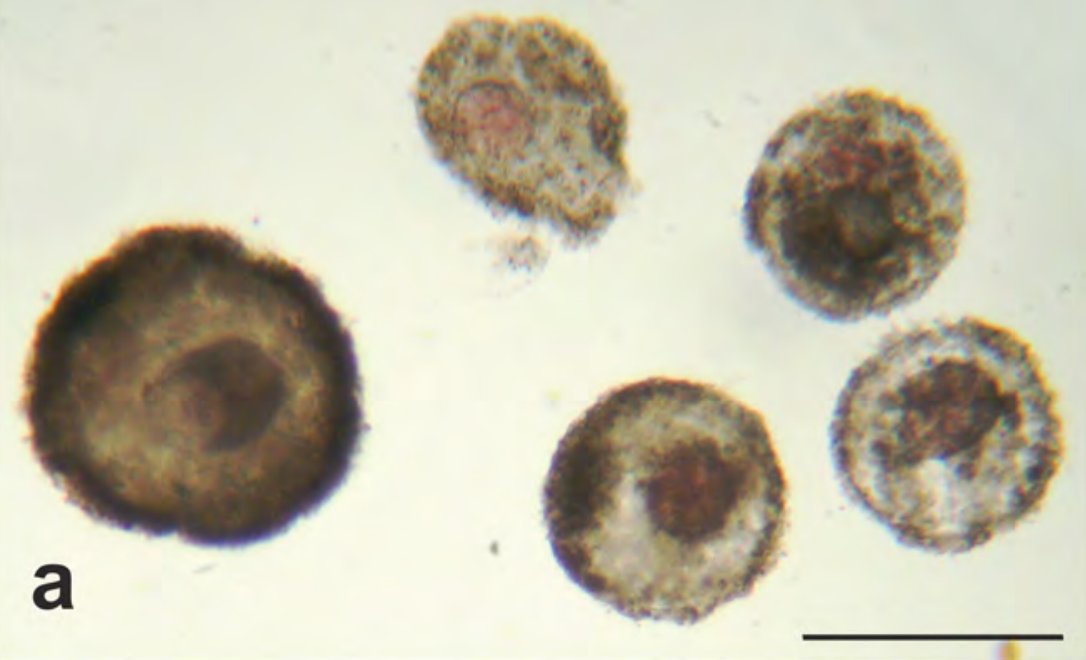
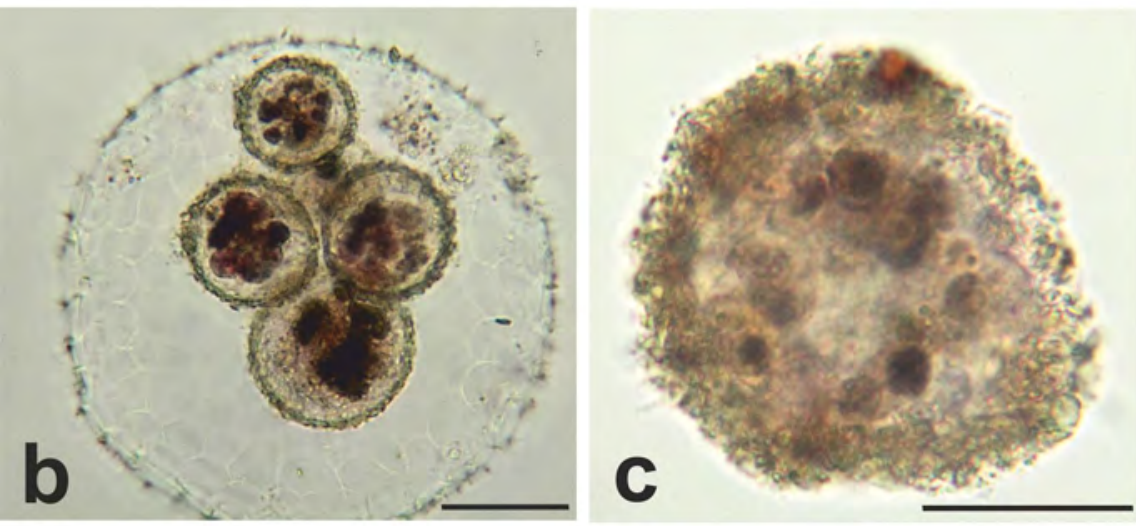
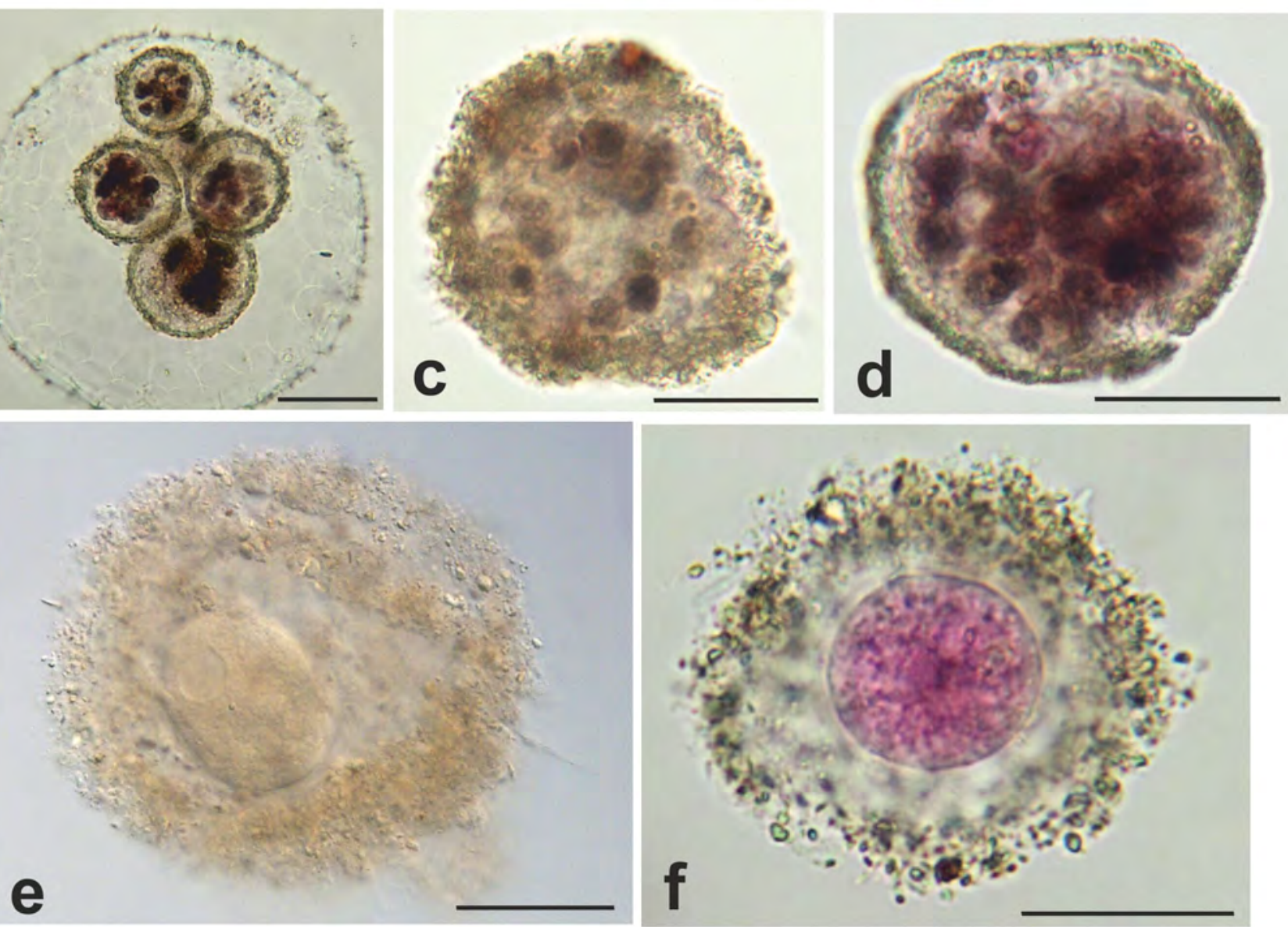